\title{
Ajengan Dadun Abdulqohhar Tokoh Ulama Kesohor Di Sukabumi (1936-2006)
}

\author{
M. Syahru Ramadlan ${ }^{1}$
}

\begin{abstract}
Abstrak
Artikel dengan judul "Ajengan Dadun Abdulqohar dan Kontribusinya dalam Pengembangan Islam di Sukabumi (1936-2006)" ini berlandaskan pada teori yang dikemukakan oleh Taufik Abdullah dalam buku Manusia dalam Kemelut Sejarah, bahwa "orang besar adalah orang yang mampu menjawab tantangan masyarakatnya sendiri”. Mereka yang terus maju menghadapi semua permasalahan dan tantangan disamping konsisten memperjuangkan ide serta cita-cita. Keberhasilan mereka menjawab tantangan tersebut dengan sendirinya memunculkan kontribusi tersendiri bagi pengembangan masyarakat. Melihat kriteria di atas, maka para alim ulama yang mempunyai nama besar dan mampu mencetak banyak kader serta mempunyai lembaga pendidikan bisa dimasukkan ke dalam golongan orang besar yang dimaksud oleh Taufik Abdullah. Ajengan Dadun adalah salah satu ulama tersebut.

Penelitian bercorak sejarah biografis ini bertujuan untuk mengungkapkan riwayat hidup, perjuangan serta kontribusi Ajengan Dadun Abdulqohhar dalam pengembangan Islam di masyarakat Sukabumi. Ajengan Dadun Abdulqohhar adalah sosok ulama karismatik yang memiliki kontribusi besar dalam pengembangan Islam di Sukabumi yang terindikasi dari lembaga pendidikan, karya tulis yang ditinggalkan, serta banyaknya murid yang meraih kesuksesan. Ajengan dadun juga tercatat sebagai penggagas pendirian Ma'had Aly di Jawa Barat dan salah satu pendiri Majlis Ulama Jawa Barat, yang kemudian dirubah menjadi MUI Jawa Barat.
\end{abstract}

Kata Kunci: Ajengan, Ulama, Biografi, Sukabumi

${ }^{1}$ Fakultas Adab dan Humaniora UIN Syarif Hidayatullah Jakarta 


\section{PENDAhuluan}

Dalam lintas sejarah Indonesia, Ulama menempati posisi penting dalam pembinaan moral masyarakat. Bahkan pada masa penjajahan, Ulama menjadi pemimpin dan konseptor perlawanan terhadap imperilalis. Dengan kata lain, kemerdekaan Indonesia tidak akan terwujud tanpa perjuangan Ulama dan umat Islam. Disamping itu, di antara peran serta kontribusi Ulama yang perlu dicatat adalah posisi mereka sebagai kelompok terpelajar yang membawa pencerahan kepada masyarakat sekitarnya, melalui berbagai lembaga yang didirikan oleh mereka, seperti Madrasah, Majlis Ta'lim, dan Pondok Pesantren. ${ }^{2}$

Kontribusi Ulama sebagai garda terdepan dalam pengembangan Islam di masyarakat dilaksanakan dengan berbagai metode, di antaranya melalui kegiatan ceramah dan pengajian di masyarakat, namun ada pula yang melakukan pendekatan berbeda seperti melalui tulisan, lembaga pendidikan, terkadang merupakan gabungan dari berbagai metode tersebut. ${ }^{3}$ Sukabumi sendiri memiliki jaringan Ulama, atau dalam istilah Sunda disebut dengan Ajengan, yang berjasa besar dalam pengembangan Islam yang sudah sepantasnya mendapatkan perhatian. ${ }^{4}$ KH Dadun Abdulqohar (w. 2006) atau lebih dikenal dengan sebutan Ajengan Dadun

2 Azyumardi Azra, Tokoh dan Pemimpin Agama, Jakarta: Badan Litbang Agama Departemen Agama RI dan PPIM, 1998, h. 212; dalam Ahmad Sofwan Hilmi, $K H$ Muhajirin Amsar Addary dan Peranannya Terhadap Perkembangan Islam di Bekasi, Skripsi Sejarah dan Peradaban Islam, UIN Syarif Hidayatullah Jakarta, 2013, h. 1.

${ }^{3}$ Dalam kasus ini dapat disebutkan nama KH Ahmad Sanusi (w.1950) sebagai salah satu pelopor dakwah Islam di Sukabumi yang multidimensi, beliau berjuang melalui ceramah, karya tulis, politik serta lembaga pendidikan.

4 Banyak ulama Sukabumi yang belum diungkapkan dalam dokumentasi komprehensif, antara lain $\mathrm{KH}$ Abdurrahim, KH Acun Mansur, KH Dadun Abdulqohar dan KH. Tangsoban. misalnya, ${ }^{5}$ adalah salah satu Ulama lokal yang telah berkontribusi dalam konteks pengembangan Islam di atas. Tentu saja di masanya beliau tidak mengembangkan Islam sendirian, tercatat ada $\mathrm{KH}$ Masturo yang juga berdakwah dengan membangun lembaga pendidikan pesantren Al-Masturiyah di daerah Cikaroya, Cisaat, Ajengan Acun Mansur yang mengembangkan Islam di daerah Tegallega, Ajengan Ahmad Sanusi, pendiri pesantren Syamsul Ulum sekaligus pendiri organisasi Al-Ittihadul Islamiyah (AII) di wilayah Gunung Puyuh. Melengkapi jajaran para pejuang dakwah tersebut, tentu tidak bisa dilewatkan pengembangan Islam yang telah dilakukan Ajengan Dadun. ${ }^{6}$

Ulama-Ulama di atas merupakan Ulama yang giat mengembangkan Islam di Sukabumi pada abad ke-20. Beberapa Ulama paling terkemuka di Sukabumi terlahir dari garis keturunan yang sama, belum ditambah tokoh lain yang pernah belajar kepada Ulama dari garis keturunan di atas yang pasti turut berjasa dalam pengembangan Islam yang membuat jaringan pengembangan Islam di wilayah Sukabumi kuat. ${ }^{7}$ Hingga saat ini, garis

${ }^{5}$ Menurut hasil penelitian A. Mukhtar Mawardi, istilah ajengan merupakan panggilan khas masyarakat sunda bagi tokoh agama yang memiliki reputasi setara dengan kyai di daerah Jawa. (lihat: A. Mukhtar Mawardi, "Haji Ahmad Sanusi Riwayat Hidup Dan Perjuangannya, skripsi, jurusan Sejarah dan Peradaban Islam Fakultas Adab, UIN Syarif Hidayatullah Jakarta, 1985, h.116.

6 Wawancara dengan KH. Nurdin Abdulqohar, putra Ajengan Dadun Abdulqohar dan Direktur KPA (Kampus Pendidikan Al-Qur'an) Ad-Da'wah Cibadak, Minggu 25 November 2012.

$7 \mathrm{KH}$ Abdurrahim, pendiri pesantren Cantayan yang disebut-sebut sebagai pesantren tertua dan cikal bakal kelahiran ulama dan tokoh terkemuka Sukabumi. Ahmad Sanusi, Dadun Abdulqohar, Acun Mansur, Mamad Maturidi, Bidin Saefuddin merupakan putraputra KH. Abdurrahim yang sangat berperan dalam mengembangkan Islam di Sukabumi. Wawancara dengan KH. Nurdin Abdulqohar, Direktur KPA AdDa’wah Cibadak, Minggu 25 November 2012. 
keturunan keluarga tersebut dikenal dengan sebutan "Keluarga Cicantayan".

Dengan melihat sejarah hidup dan perjuangan mereka, keberadaan Ulama-Ulama tersebut memiliki kontribusi penting bagi masyarakat, baik dalam konteks pengembangan intelektual keagamaan, ekonomi, sosial, maupun aspek politis. Dari aspek intelektual misalnya, upaya yang dilakukan para Ulama dalam mencerdaskan masyarakat Sukabumi secara umum dilaksanakan dengan mendirikan lembagalembaga pendidikan Islam berupa Madrasah, Majlis Ta'lim, Pondok Pesantren yang jumlahnya sangat banyak. Tradisi pendidikan Islam dalam bentuk lembaga pendidikan Islam dan Pondok Pesantren yang dikembangkan oleh mereka pada hakikatnya merupakan bagian dari usaha untuk meneruskan tradisi keilmuan guru-guru mereka dalam mentransmisikan ilmu-ilmu Islam yang pada akhirnya menciptakan sebuah jaringan intelektual tersendiri. Dari aspek ekonomi misalnya, kiprah para Ulama ini memberi dampak positif bagi peningkatan kesejahteraan masyarakat, terutama bagi kondisi perekonomian di sekitar lembaga pendidikan yang ada. Sedangkan dalam aspek politis, perjuangan mereka secara langsung dan tidak langsung telah menanamkan semangat patriotisme dalam membela agama dan Negara. Adapun peran positif dalam aspek sosial-budaya diindikasikan dengan hilangnya tradisi-tradisi lama yang tidak sesuai dengan Islam dan lahirnya tradisi baru di masyarakat, seperti tradisi saling menolong yang berasal dari konsep silaturahmi.

Secara teoritis Taufik Abdullah mengatakan bahwa orang besar adalah orang yang berhasil menjawab tantangan masyarakatnya, maupun tantangan yang

${ }^{8}$ Wawancara dengan Hilman Sulaeman, tenaga pengajar dan Humas SDIT Ad-Da'wah, Sabtu 24 November 2012; lihat pula bulletin Adz-Zurriyyat edisi perdana, 2005. mengitari dirinya. ${ }^{9}$ Jika kita melihat kriteria di atas, maka para ulama layak disebut sebagai salah satu dari golongan orang besar tersebut. Mereka yang terus maju menghadapi semua permasalahan dan tantangan disamping konsisten memperjuangkan ide serta citacitanya.

Aktivitas dakwah Ajengan Dadun mulai terlihat di masyarakat ketika mendirikan Yayasan Majlis Ta'lim Ad-Da'wah pada tahun 1964 yang membawahi puluhan Sekolah, Madrasah, Pesantren dan Majlis Ta'lim dengan unit cabang tersebar ke berbagai daerah, di antaranya Sukabumi, Bogor, Cianjur dan Jakarta. Banyak muridmurid beliau yang telah menjadi ulama maupun tokoh masyarakat, di antaranya $\mathrm{KH}$. Didin Hafiduddin, KH.E. Zaenal Abidin, KH. Khalil Ridwan, Bapak Sukma Wijaya, Bupati Sukabumi saat ini termasuk dua generasi Bupati sebelumnya yakni bapak Ahwani Zainuddin dan Maman Sulaeman.

\section{PEMBAHASAN}

\section{A. Riwayat Kelahiran}

Di tengah-tengah kondisi sosial-ekonomi dan budaya seperti yang telah dipaparkan sebelumnya, lahirlah seorang anak laki-laki yang di kemudian hari menjadi seorang ulama kharismatis yang sangat disegani. Anak lakilaki itu bernama Dadun Abdulqohhar, atau kelak lebih dikenal dengan sebutan Ajengan Dadun, yang lahir di desa Cantayan, Sukabumi pada tanggal 23 September 1923 bertepatan dengan tanggal 5 Syawal $1341 \mathrm{H}$ sebagai putra kelima dari sembilan bersaudara buah cinta pernikahan KH. Abdurrahim dengan istri keduanya, Siti Zaenab. Delapan saudaranya yang lain, sebagaimana tercantum dalam dokumen Silsilah Keluarga AMA KH. Abdurrahim, masing-masing bernama Acun

\footnotetext{
9 Taufik Abdullah, "Manusia dalam Kemelut Sejarah, Sebuah Pengantar", dalam Manusia dalam Kemelut Sejarah, Taufik Abdullah dkk, (Ed), LP3ES, Jakarta: 1983, cet-4, h.10.
} 
Mansyur, Damanhuri, Siti Muznah, Anfasiah, Muhammad Maturidi, Bidin Saefudin, Ammatul Jabbar dan Abdul Malik, Sementara dari istri pertama, Empok, KH. Abdurrahim dikaruniai delapan orang putra putra-putri, yakni Iting, Abdullah, Ahmad Sanusi, Endah, Ulan, Soleh, Hanafi dan Nahrowi. ${ }^{10}$

KH. Abdurrahim sendiri merupakan seorang ulama yang cukup terkemuka di Sukabumi pada saat itu karena beliau merupakan pendiri pondok pesantren Cantayan. ${ }^{11}$ Dalam wawancara dengan $\mathrm{KH}$. Nurdin Abdulqohhar pada Minggu pagi yang bertempat di kantor SDIT Ad-Da'wah, putra Ajengan Dadun yang kini menjabat sebagai ketua Yayasan Ad-Da'wah, dikatakan bahwa pesantren Cantayan adalah pesantren tertua di Sukabumi, dan karena pesantren ini pula, KH. Abdurrahim mendapat julukan sebagai Ajengan Cantayan. ${ }^{12}$

Dalam buku Riwayat Perjuangan KH. Ahmad Sanusi dipaparkan bahwa berdasarkan cerita lisan di lingkungan keluarga dan masyarakat sekitarnya, KH. Abdurrahim berasal dari Sukapura (Tasikmalaya). ${ }^{13}$ Konon

10 Silsilah keluarga Ama KH. Abdurrahim, Pusat Informasi Keluarga (PIK), Pesantren Putri Tarbiyatun Nisaa, Rancabungur, Bogor, h. 2.

${ }^{11}$ Selain menjadi pesantren tertua di Sukabumi, pesantren Cantayan juga sempat dijadikan basis perjuangan umat Islam Sukabumi melawan penjajah Belanda. Hal inilah yang membuat pesantren Cantayan dan $\mathrm{KH}$ Abdurrahim menjadi terkenal. Memang di wilayah manapun, sosok Ajengan tidak saja sebagai pemimpin dibidang keagamaan namun juga sebaga figur yang sanggup mengobarkan semangat berjihad antikolonialisme Belanda, lihat Sukamto, Kepemimpinan Kyai dalam Pesantren, LP3ES, Jakarta 1999, h. 76-77.

12 Dari pesantren Cantayan ini terlahir banyak ulama dan tokoh berpengaruh yang tersebar di berbagai wilayah Sukabumi dan Jawa Barat, termasuk salah satunya putra KH Abdurrahim sendiri, yakni Dadun Abdulqohhar, Wawancara dengan Nurdin Abdulqohar, putra Ajengan Dadun dan ketua yayasan Majlis Ta'lim Ad-Da'wah Cibadak, Minggu 25 November 2012.

13 Keterangan dalam buku ini juga sesuai dengan keterangan yang penulis dapatkan dari hasil wawancara dengan KH Nurdin Abdulqohhar; lihat juga "Ikhtisar Hasil Silaturahmi Keluarga Besar Cantayan Sukabumi diceritakan bahwa ayah KH. Abdurrahim yang bernama $\mathrm{H}$ Yasin masih memiliki hubungan kekeluargaan dengan Raden Anggadipa. ${ }^{14}$ Ketika memegang jabatan sebagai Bupati Sukapura, Raden Anggadipa dikenal dengan nama Raden Tumenggung Wiradadaha III. Ia dikenal juga dengan panggilan Dalem Sawidak karena memiliki anak sekitar enam puluh orang. Senada dengan keterangan ini, majalah Ad-Dzurriyyat juga menyebutkan bahwa $\mathrm{H}$ Yasin merupakan keturunan Syekh Abdul Muhyi, penyebar agama Islam di daerah Tasikmalaya Selatan yang berpusat di Pamijahan.

Keturunan dari Syeikh Abdul Muhyi pun kemudian menyebar ke berbagai wilayah di Jawa Barat untuk meneruskan perjuangan da'wah Islam yang telah dilakukan oleh para pendahulunya. Salah satu dari mereka adalah $\mathrm{H}$ Yasin. Sebagaimana tertulis dalam bulletin keluarga besar Cantayan, diceritakan bahwa H. Yasin berangkat mengembara dari Tasikmalaya ke berbagai wilayah di Jawa Barat hingga akhirnya tiba di Sukabumi serta memutuskan untuk menetap di daerah yang sekarang bernama Cantayan. Selama pengembaraannya, ia ditemani istrinya yang bernama Naisari. Dari perkawinannya itu, $\mathrm{H}$. Yasin memiliki sepuluh orang putra dan salah satunya bernama KH. Abdurrahim sebagai anak keenam. Lima orang kakaknya masingmasing bernama Sardan, Eming, Ja'ud Coon, Maryam, dan Iti. Sementara itu, empat orang adiknya masing-masing bernama Fatimah, Madjid, Eming Emot, dan Rohman. ${ }^{15}$

Di desa Cantayan inilah Ajengan Dadun menghabiskan masa kecil bersama saudarasaudaranya dengan belajar ilmu agama dan

Keturunan KH Abdurrahim" dalam Bulletin AdzDzurriyat, edisi perdana, 2005, h. 9.

14 Misbahul Falah, Riwayat Perjuangan KH Ahmad Sanusi, Masyarakat Sejarawan Indonesia Cabang Jawa Barat, Sukabumi, 2009, h. 12.

15 Misbahul Falah, Riwayat Perjuangan KH Ahmad Sanusi, h.13; lihat juga Silsilah keluarga Ama KH. Abdurrahim, Pusat Informasi Keluarga (PIK), Pesantren Putri Tarbiyatun Nisaa, Rancabungur, Bogor. 
Al-Qur'an di bawah bimbingan kedua orang tuanya. Sebagai seorang anak Ajengan, sejak kecil Ajengan Dadun beserta dengan seluruh saudaranya dididik dalam lingkungan religius. Seperti halnya tradisi masyarakat di berbagai daerah lain, dalam kehidupan sehari-hari Ajengan Dadun mendapat perlakuan istimewa dari para santri dan masyarakat sekitarnya sebagai bentuk penghormatan masyarakat terhadap keluarga ulama yang begitu tinggi karena kedalaman ilmu agamanya. Ajengan atau Kyai memang merupakan kelompok sosial di masyarakat yang memiliki pengaruh sangat kuat sehingga keberadaannya dipandang sebagai salah satu kekuatan penting dalam kehidupan politik. Akibatnya, Kyai merupakan pembuat keputusan yang efektif dalam sistem sosial, tidak hanya dalam kehidupan keagamaan, tetapi juga dalam kehidupan politik. $^{16}$

Ajengan Dadun lahir pada masa penjajahan, ketika Belanda saat itu masih kuat menguasai tatanan pemerintahan. Kondisi ini menyebabkan rakyat Sukabumi tertindas secara ekonomis dan sosial serta terbelakang dalam pendidikan dan pola berfikir akibat dari perlakuan semena-mena pihak kolonial. Namun beruntung, di tengah keterpurukan tersebut, ada pihak-pihak yang berdiri menentang penjajah. Di tengah segala keterbatasan akibat ketatnya kontrol pemerintah Belanda terhadap pribumi, mereka mengobarkan semangat juang untuk terus maju.

\section{B. Sekilas Tentang Keluarga Cantayan}

Keluarga Cantayan merupakan istilah yang tidak asing di telinga masyarakat Sukabumi, terutama bagi mereka yang berkecimpung dalam dunia dakwah, pesantren, dan pemerintahan. Istilah ini merujuk kepada keluarga besar yang diakui oleh berbagai kalangan, terutama tokoh masyarakat dan ulama Sukabumi sebagai

${ }^{16}$ Zamaksyari Dhofier, Tradisi Pesantren: Studi Tentang Pandangan Hidup Kyai, Jakarta, LP3ES, 1982, h. 56. keluarga "alim ulama" yang memiliki pengaruh kuat dalam strata sosial dan keagamaan di wilayah Sukabumi, hal ini dikarenakan banyaknya anggota keluarga Cantayan yang menjadi tokoh terkemuka. Dua di antaranya, KH. Ahmad Sanusi dan Dadun Abdulqohhar bahkan sangat berpengaruh di Sukabumi dan Jawa Barat.

Sebagaimana telah disebutkan sebelumnya bahwa Pesantren Cantayan yang didirikan oleh KH. Abdurrahim disebut-sebut sebagai pesantren tertua di Sukabumi yang pernah menjadi basis perjuangan melawan penjajah dan telah melahirkan banyak pejuang dan tokoh agama. Banyak pula AjenganAjengan Jawa Barat dan tokoh masyarakat yang telah dilahirkan melalui kiprah dakwah keluarga Cantayan. Sekarang ini generasi terakhir dari angkatan pertama keturunan $\mathrm{KH}$. Abdurrahim sudah tiada dengan meninggalnya Ajengan Dadun pada tahun 2006 silam, namun keluarga besar Cantayan masih sangat dihormati karena kiprahnya dalam bidang da'wah, pendidikan serta pengembangan Islam.

\section{Masa Muda dan Pendidikan}

Ajengan Dadun memulai masa pendidikan sejak umur enam tahun. Di usia itu, Ajengan Dadun belajar ilmu agama di pesantren Cantayan asuhan orang tuanya, $\mathrm{KH}$. Abdurrahim. Setelah dirasa cukup mendapatkan dasar-dasar ilmu agama dari orang tuanya, Ajengan Dadun lantas melanjutkan proses belajar dengan berguru kepada selain ayahnya. Beberapa ulama yang diketahui menjadi guru beliau di antaranya adalah Ajengan Uci atau yang biasa dipanggil Muallim Uci, pendiri pesantren Nurul Huda Cikaroya, Sukabumi. Muallim Uci merupakan murid dari kakek Ajengan Dadun (Haji Yasin), karena beliau cerdas maka ditugaskanlah oleh Haji Yasin untuk mengajar dan menjadi guru Ajengan Dadun. Selain Muallim Uci, Ajengan Dadun juga berguru kepada beberapa ulama, namun menariknya, 
hampir semua guru beliau masih merupakan saudara sendiri, mereka adalah: ${ }^{17}$
1. K. Ahmad Nahrowi (kakak)
2. KH. Acun Mansur (kakak)
3. K Ahmad Damanhuri (kakak)

Selain berguru kepada mereka, Ajengan Dadun juga belajar kepada KH. Ahmad Sanusi yang merupakan kakak tiri beliau (karena berbeda ibu) dari tahun 1938 hingga 1940 di madrasah Syamsul 'Ulum, pesantren Gunung Puyuh, Sukabumi. ${ }^{18}$ Satu hal menarik untuk dicermati adalah sebagian besar guru Ajengan Dadun merupakan anggota keluarga sendiri. Ajengan Dadun juga tidak pernah pergi ke Timur Tengah untuk memperluas wawasan dan memperdalam pengetahuan seperti layaknya kebiasaan ulama ternama lainnya. Ini bukan karena beliau tidak mempunyai hasrat dan keinginan untuk menimba ilmu di pusat studi ilmu Islam utama dunia, namun lebih dikarenakan aktifitas dakwah yang sangat padat yang membuat beliau tidak mempunyai banyak waktu dan kesempatan. Sebab di usia 11 tahun saja Ajengan Dadun sudah menerima banyak permintaan untuk ceramah, pengajian dan memberikan pengajaran agama di berbagai wilayah.

Faktor selanjutnya adalah kepulangan KH. Ahmad Sanusi setelah sekian tahun belajar dan menetap di Mekah. Menurut Ajengan Dudun Abdul Ghaffar, sahabat sekaligus murid Ajengan Dadun, sosok Ajengan Sanusi sangat berpengaruh bersar dalam pembentukan cara pandang dan keilmuan Ajengan Dadun. Bahkan di tingkat yang lebih luas, sempat ada berita yang mengatakan bahwa maraknya pembelajaran kitab Tafsir Jalalain di pesantren-pesantren

17 Biodata KH Dadun Abdulqohhar, Ketua Umum Yayasan Majlis Ta'lim Ad-Da'wah. Sesepuh Pesantren Ad-Da'wah Cibadak, Sukabumi, 1993, h. 1.

18 Biodata KH Dadun Abdulqohhar, Ketua Umum Yayasan Majlis Ta'lim Ad-Da'wah. Sesepuh Pesantren Ad-Da'wah Cibadak, Sukabumi, 199, h. 2. adalah karena pengajaran yang dilakukan Ajengan Sanusi. ${ }^{19}$

Kedekatan antar anggota keluarga $\mathrm{KH}$. Abdurrahim memang tidak sekedar kedekatan emosional, namun juga intelektual. Ajengan Sanusi sering berdiskusi dan berbincang dalam konteks keilmuan dengan saudarasaudaranya termasuk Ajengan Dadun, terkadang serius dan terkadang diselingi candaan, sehingga terjadi transmisi wawasan, pola fikir dan keilmuan. Dan di antara sekian anggota keluarga, Ajengan Dadun memiliki kecerdasan di atas rata-rata sehingga mampu menyerap berbagai pemikiran, keilmuan, dan mengembangkannya, sehingga sangat diayomi dan dibanggakan oleh seluruh anggota keluarganya. $^{20}$

Karena itu, meski tidak pernah belajar kepada ulama terkemuka di Timur Tengah, Ajengan Dadun memiliki kualitas yang tidak kalah, bahkan jauh mengungguli mereka yang bertahun-tahun belajar di sana. Disamping itu, karena ketinggian ilmunya, beliau juga mampu mengetahui alam pikiran, karakter dan kemampuan seseorang tanpa harus berdialog terlebih dahulu.

Dengan bekal kecerdasan, kesungguhan dalam belajar dan berbagai disiplin ilmu yang diperoleh dari keluarganya, Ajengan Dadun kemudian, perlahan tapi pasti, mulai memberikan pengajaran dan mentransmisikan keilmuan yang beliau milliki melalui berbagai macam cara, dari mulai menjadi da'i yang mengharuskan beliau singgah ke berbagai tempat, memberikan tausiyah dan pengajian di berbagai majlis ta'lim, hingga mendirikan Yayasan Ad-Da'wah, pesantren dan berbagai unit cabang di berbagai wilayah serta menulis buku. Da'wah yang dilakukan Ajengan Dadun tidak terbatas pada kalangan tertentu tapi menyentuh semua lapisan masyarakat, mulai

19 Wawancara dengan Dudun Abdul Ghoffar, ketua Yayasan Al-Basyriyyah Cicantayan, Minggu, 5 Mei, 2013.

${ }^{20}$ Wawancara dengan KH Nurdin Abdulqohhar, Direktur KPA Ad-Da'wah Cibadak, Minggu 25 November 2012. 
dari kalangan sesama Ajengan, cendekiawan, para pejabat pemerintahan, para pendidik, kader da'wah, santri, pedagang, petani, pemuda, pegawai negeri, dan akademisi. Meski memang Ajengan Dadun tidak pernah mengenyam pendidikan formal, tetapi berkat berkah dari ilmu yang beliau pelajari dari guru-guru dan didukung oleh kecerdasan dan ketekunannya dalam belajar secara otodidak membuat beliau menjadi sosok yang berwawasan luas, bijaksana serta dikenal sebagai tokoh karismatis yang disegani masyarakat. $^{21}$

Di sela- sela aktifitas perjuangannya, Ajengan Dadun menikah dengan empat orang istri dan dikaruniai 19 orang putera-puteri. Dari istri pertama yakni ibu Ikoh, Ajengan Dadun memiliki empat orang anak; Tati, Syarif Hidayat, Zainal Arifin dan Muhammad AR. Dari istri kedua yaitu ibu Juhairiyah (Juariyah) lahir 13 anak; Lukman, Yusuf Efendi, Taufikurrahman, Dadang Sholahuddin, Euis Nurhayati, Jauhar, Cecep Luthfi, Nurdin Abdulqohhar, Heni Juhaeni, Ida Farida, Cucu Lidya, Asep Abdulqadir, Ela Nurlaela. Kemudian dari istri ketiga, Ibu Nana dikaruniai dua orang anak; deni Abdulqohhar dan Aliyah. Sementara dari istri keempat, ibu Ai Sofiah tidak dikarunia putra. ${ }^{22}$

${ }^{21}$ Dalam bulletin Ad-Dzurriyyat disebut bahwa sebagian besar putra-putri KH Abdurrahim di didik dan belajar dasar-dasar ilmu agama langsung dari KH. Abdurrahim sendiri dan kemudian mereka pun belajar sendirisendiri dengan otodidak tanpa pernah mengenyam sekolah yang saat itu didirikan oleh Belanda, "Haram bagi keluarga untuk belajar di sekolah Belanda", demikian prinsip KH. Abdurrahim pada saat itu. Wawancara dengan Dudun Abdul Ghoffar, ketua Yayasan Al-Basyriyyah Cicantayan, Minggu, 5 Mei, 2013, lihat pula Bulletin Adz-Dzurriyat, edisi perdana, 2005, h. 10; lihat pula Anna Mariana, Pengaruh Khitobah KH Dadun Abdulqohhar Dalam Meningkatkan Pemahaman Keagamaan Masyarakat (penelitian di Majlis Ta'lim Ad-Da'wah Cibadak Sukabumi), h. 47.

22 Silsilah keluarga Ama KH. Abdurrahim, Pusat Informasi Keluarga (PIK), Pesantren Putri Tarbiyatun Nisaa, Rancabungur, Bogor, h.5.

\section{Kepribadian Dadun Abdulqohhar}

Ada semacam keyakinan di masyakat bahwa anak seorang ulama, terlebih ulama besar akan selalu memiliki keistimewaan yang tidak selalu ditemukan pada anak-anak biasa. Terkadang keistimewaan itu terlihat aneh dan nyeleneh namun mempertegas kelebihan yang dimiliki anak itu. Meski keyakinan tersebut agak berbau mitos dan berlebihan namun hal itu seringkali memang benar adanya. ${ }^{23}$ Begitu pula dengan Dadun Abdulqohhar di masa remaja. Terlahir dari garis keturunan mulia dan terhormat serta tumbuh dalam keluarga yang kuat secara spiritual dan tradisi intelektual, Dadun Abdulqohhar sudah dikenal memiliki kelebihan yang tidak ditemui pada anak lain seusianya. Sejak kecil beliau dikenal memiliki kecerdasan yang jauh di atas ratarata, "Sakali baca teks atau kitab (kuning), kitab naon wae, Hadits, Jurumiyah, Alfiyah, pokona kitab-kitab, langsung hafal jeung isiisina”," 24 (sekali baca teks atau kitab kuning, kitab apa saja, Hadits, Jurumiyah, Alfiyah Ibn Malik, pokoknya semua kitab, langsung hafal dengan isi-isinya), ujar KH. Nurdin Abdulqohhar ketika menggambarkan

${ }^{23}$ Pengalaman penulis semasa mengenyam pendidikan di salah satu pesantren Jawa Timur, kyai-kyai besar selalu memiliki kelebihan unik yang biasa dikaitkan dengan ilmu ladunni serta kemampuan metafisik. Contoh $\mathrm{KH}$ Maktum Jauhari, pemimpin pesantren Al-Amien Prenduan, sejak kecil beliau terkenal dianugerahi ilmu ladunni, selalu tertidur disaat pengajaran sekolah dan pengajian namun selalu mampu menjawab soal ujian tanpa harus "susah payah" belajar, bahkan beliau sempat akan dianugerahi gelar Doktor termuda se-Asia Tenggara karena kecerdasan yang dimilikinya, namun ditolak oleh beliau dengan alasan tertentu. Atau bagaimana seorang putra kyai dari wilayah Prenduan, Sumenep Madura bisa bergerak seperti seolah-olah menghilang pada malam hari, dan masih banyak lagi fakta lapangan yang menegaskan bahwa merupakan hal yang lazim jika ditemukan tanda-tanda istimewa pada keluarga ulama atau kyai, yang bisa saja merupakan pengaruh oleh garis keturunan (waliyullah, bangsawan) atau semata-mata merupakan mazi'ah atau kelebihan yang diberikan Allah SWT.

24 Wawancara dengan KH Nurdin Abdulqohhar, Direktur KPA Ad-Da'wah Cibadak, Minggu 25 November 2012. 
bagaimana kecerdasan Ajengan Dadun di masa kecil. Maka tidak heran bahwa pada saat itu semua saudaranya memperlakukan beliau dengan istimewa, menjadi kebanggaan keluarga karena memiliki kelebihan yang menonjol di antara yang lainnya. Karena kelebihan ini pula, di usia 11 tahun, ketika teman-teman sebayanya pada saat itu masih asik bermain-main atau menggembala hewan, Dadun Abdulqohhar muda sudah menjadi seorang dai, muballigh terkenal di Sukabumi yang selalu berkelana ke berbagai pelosok daerah demi memenuhi panggilan masyarakat. Selain tersohor sebagai dai cilik, di usia itu beliau juga sudah hafal Al-Qur'an. ${ }^{25}$

Selain dianugerahi kecerdasan dan keterampilan dalam ceramah, Dadun Abdulqohhar muda merupakan sosok yang ramah serta mudah bergaul dan berbaur dengan orang lain, hormat dan peduli kepada teman, serta sangat takzim kepada guru dan orang tua. Ajengan Dadun sangat ta'zim kepada guru, meski hampir semua yang menjadi guru beliau masih merupakan keluarga tapi penghormatan yang beliau berikan lebih dari sekedar ikatan saudara, selayaknya penghormatan antara santri dan Kyai. Sikap seperti ini memang merupakan hasil dari pengajaran tata krama yang diajarkan ayahnya, KH. Abdurrahim sebagai bentuk penghargaan dan adab sopan santun murid kepada guru. KH. Abdurrahim sendiri, sebagaimana keterangan yang diberikan $\mathrm{KH}$. Muhammad AR, sangat menghargai dan menghormati semua yang menjadi guru Ajengan Dadun, meskipun semua yang menjadi guru tidak lain masih merupakan keluarganya sendiri. ${ }^{26}$

${ }^{25}$ Wawancara dengan KH Nurdin Abdulqohhar, Direktur KPA Ad-Da'wah Cibadak, Minggu 25 November 2012; lihat pula Muhsin Fadhli, Peran Da'wah Kyai Haji Dadun Abdulqohhar dalam Membina Masyarakat Cibadak-Sukabumi. Skripsi Komunikasi Penyiaran Islam, STID Mohammad Natsir Jakarta, 2012, h. 44.

26 Wawancara dengan KH Muhammad, Jum'at 19 April 2013, pukul 18.30-20.00 WIB.
Setelah dewasa, sebagai seorang ayah, Ajengan Dadun merupakan sosok teladan sekaligus guru bagi seluruh anggota keluarga. Sikap beliau, terutama jika menyangkut masalah keagamaan sangat tegas, terkadang keras, namun masih dalam koridor yang positif. $^{27}$ Memang diakui karakter Ajengan Dadun yang keras dan tegas, ditambah kharisma yang dimiliki seringkali membuat anak-anaknya merasa segan untuk berkomunikasi secara akrab layaknya potret keluarga modern saat ini. Bahkan masih lekat dalam ingatan KH. Nurdin Abdulqohhar, dikarenakan begitu besarnya kharisma Ajengan Dadun, seringkali ketika Ajengan Dadun pulang dari aktifitas dakwah di malam hari, anak-anak yang tadinya sedang asik berkumpul di ruang tengah dengan ibunya langsung berhamburan ke kamar masingmasing saat mendengar bunyi klakson mobil pertanda kepulangan ayah mereka, alasan semua anak-anaknya sama, takut mengganggu kebersamaan ayah dan ibunya. ${ }^{28}$ Namun hal itu bukan berarti anak-anak tidak suka, melainkan lebih kepada sikap ta'zim dan hormat terhadap ayah mereka.

Pembawaan tersebut juga tampak dalam aktifitas dakwah dan interkasi kesehariannya, jika sudah berkata "salah" ya salah, jika menurut Ajengan Dadun "A" berarti harus tetap A. Sikap ini tidak lantas menunjukkan Ajengan Dadun keras kepala dan suka memaksakan kehendak secara asal-asalan, namun lebih memperlihatkan bahwa beliau memiliki keyakinan diri yang kuat bahwa semua yang dikatakan memilliki landasan ilmu dan pemikiran yang jelas. disamping itu Ajengan Dadun juga terkenal berani dalam menyuarakan kebenaran, tidak takut kepada apapun, baik kepada penjajah, pejabat

27 Muhsin Fadhli, Peran Da'wah Kyai Haji Dadun Abdulqohhar dalam Membina Masyarakat CibadakSukabumi. Skripsi Komunikasi Penyiaran Islam, STID Mohammad Natsir Jakarta, 2012, h. 43.

${ }^{28}$ Wawancara dengan KH Nurdin Abdulqohhar, Direktur KPA Ad-Da'wah Cibadak, Minggu 25 November 2012. 
pemerintahan, dan siapa pun kecuali kepada Allah. ${ }^{29}$

Keilmuan yang mumpuni ditambah kualitas diri yang seperti itu menjadikan Ajengan Dadun menjadi sangat berpengaruh di masyarakat. KH. Nurdin Abdulqohhar mengatakan bahwa semua karakter yang beliau miliki membuat pihak keluarga masih belum bisa meneladani beliau seratus persen dan sangat susah mencari penggantinya. Sampai saat ini pun, seluruh pihak keluarga mengakui belum dirasakan lagi ada sosok yang mempunyai pengaruh serta karisma yang setara dengan Ajengan Dadun di Sukabumi.

Hingga memasuki usia senja, Ajengan Dadun tetap konsisten melakukan kegiatan dakwah. Meski dengan kondisi yang tidak lagi sehat seperi dahulu dan kadang jatuh sakit, beliau tetap aktif mengajar, memberi ceramah di majlis-majlis ta'lim, Khutbah Jum'at dan acara lain. Tiada hari tanpa mengamalkan ilmu dan menyeru masyarakat untuk selalu menjalani kehidupan sehari-hari yang berdasarkan petunjuk Al-Qur'an dan AsSunnah.

\section{E. Pemikiran dan Pandangan Hidupnya}

Ajengan Dadun mencurahkan seluruh hidupnya demi dakwah Islam. Selama perjalanan panjang dakwahnya itu, Ajengan Dadun dikenal sebagai ulama yang gigih memperjuangkan kemurnian ajaran Islam melalui konsep pemikiran Dinul Islam, yang kemudian menjadi ciri khas dakwah dan pemikirannya. Bagi Ajengan Dadun, AlQur'an merupakan pedoman mutlak bagi terciptanya kehidupan duniawi yang ideal, kehidupan yang selaras dengan apa yang telah digariskan Allah SWT.

Esensi dari setiap kegiatan dakwah yang dilakukan merupakan upaya untuk meluruskan kembali pemahaman bahwa Islam adalah satusatunya sistem yang kaffah, menyeluruh,

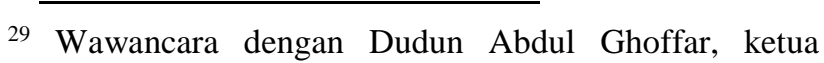
Yayasan Al-Basyriyyah Cicantayan, Minggu, 5 Mei, 2013. universal, yang mampu memberikan jaminan terciptanya kedamaian, ketenangan, kerukunan kesejahteraan, kebahagiaan hidup dunia dan akhirat. Namun pengertian Islam ini berbeda dengan kondisi faktual di masyarakat, seperti masih adanya dikotomi antara ilmu pengetahuan agama dan umum, padahal menurut Ajengan Dadun, Islam adalah "satu totalitas yang tidak bisa dipecah atau dibagi". Antara satu dan yang lain saling berkaitan. Sebagai contoh, jika berbicara permasalahan ekonomi, maka Islam sebagai sistem yang sudah jelas mengatur aspek ekonomi berbasis Al-Qur'an sudah seharusnya menjadi acuan, begitu juga bidang-bidang lainnya. ${ }^{30}$

Oleh sebab itu, Ajengan Dadun terdorong untuk melakukan perbaikan, mengadakan pembinaan umat dengan dimulai dari pelurusan pemahaman mengenai Islam. Hal ini juga salah satunya yang kemudian melatarbelakangi pendirian Yayasan AdDa'wah pada tahun 1964 dan kemudian pada tahun 1978 diaktanotariskan dengan nama Yayasan Majlis Ta'Iim Ad-Da'wah, yang menjadi wadah perjuangan beliau. Dari sini kemudian didirikan unit-unit pembinaan berupa majlis ta'lim, madrasah dan sekolah yang tersebar ke berbagai wilayah seperti Sukabumi, Bogor, Banten, Cianjur dan Jakarta.

Salah satu contoh perbaikan yang bisa diambil adalah tradisi tarawih di bulan Ramadhan. Dalam sebuah hadits rasul bersabda "Shalatlah sebagaimana aku mengerjakannya". Ajengan Dadun berpendapat bahwa shalat tarawih sebagaimana yang ada saat ini tidak pernah dilakukan oleh rasul, yang ada adalah shalat malam. Oleh sebab itu Ajengan Dadun mempraktekan di masjid Ad-Da'wah, meski pada awalnya dianggap aneh, namun seiring berjalan waktu dan meningkatnya pemahaman

30 Anna Mariana, Pengaruh Khitobah KH Dadun Abdulqohhar dalam Meningkatkan Pemahaman Keagamaan Masyarakat (penelitian di Majlis Ta'lim Ad-Da'wah Cibadak Sukabumi), h. 49. 
masyarakat, sambutan yang diterima kian positif dan suasana malam setiap bulan ramadhan pun menjadi semakin semarak. Mengerjakan shalat malam sesuai dengan sunnah rasul yang kemudian dilanjutkan dengan sahur bersama. Ini adalah potret kecil dari implementasi pemikiran beliau mengenai pemurnian pemahaman Islam. ${ }^{31}$

Dalam sesi wawancara dengan $\mathrm{KH}$ Nurdin Abdulqohhar, putra kelima dan merupakan satu-satunya anak yang selalu diikutkan dalam setiap kegiatan dakwah Ajengan Dadun, dijelaskan bahwa pola pemikiran Dinul Islam yang dikembangkan Ajengan Dadun merupakan pengadopsian sekaligus pembenahan istilah yang sama seperti yang dulu dipakai oleh rasul dan sahabat ketika melakukan dakwah. Ketika ajaran Islam yang masuk ke berbagai wilayah, termasuk Indonesia, kondisinya sudah mengalami interaksi dengan berbagai kebudayaan. Kondisi masyarakat Indonesia saat itu juga beraneka ragam, ada animisme, dinamisme, Hindu, Budha, sehingga adanya asimilasi dengan kebudayaan lokal pun tidak dapat dihindari, yang pada akhirya bisa dikatakan bahwa ada beberapa aspek keislamaan saat ini yang berbeda dari Islam yang diajarkan rasul. Inilah yang dalam sebuah hadits digambarkan oleh rasul bahwa akan tiba pada suatu masa dimana Islam itu sudah tidak murni lagi karena terkontaminasi unsur-unsur dari luar, yang dalam haditsnya dianalogikan dengan dukhan (asap), debu yang mengotori Islam, seperti asap rokok.

Pak Nurdin kemudian mencontohkan dengan meniupkan asap rokok ke telapak tangan, "kalo ditiupkan kesini pasti ada bekasnya kan? Nah itulah kondisi Islam setelah ditinggal jauh oleh rasul. Tapi ingat lho, ajaran Islam dan esensinya tetap murni, "Al-Islammu ya'lu wa la yu'la alaihi", tidak ada yang lebih tinggi (murni) dari Islam, tapi interaksinya dengan kebudayaan dari luar

31 Anna Mariana, Pengaruh Khitobah KH Dadun Abdulqohhar, h. 49. menyebabkan lahirnya hal-hal baru seperti cara penyampaian serta berbagai intrepretasi baru dalam Islam, sehingga lahirlah warna Islam yang beraneka ragam yang beberapa diantaranya sebenarnya tidak sama dengan ajaran yang dibawa nabi pada saat beliau masih hidup. Ini yang dalam hadits dimaksud dengan "Khairun wa fiihi dakhonun", Islam itu baik, namun ada noda asap yang mengotori". 32

Padahal jika dicermati dengan baik, Islam merupakan agama yang paling universal dan terjaga kemurniannya karena Islam datang dari Allah. Surat Al-Imran ayat 19 menegaskan, Innaddiina 'Indallahil Islam, Sesungguhnya agama (yang diridhai) disisi Allah hanyalah Islam. Inilah landasan pemikiran konsep Dinul Islam yang kemudian diikuti dengan pembenahan unsurnya yakni Iman, Islam dan Ihsan. Hal yang perlu diperhatikan, dalam konsep pemikiran Dinul Islam ini Ajengan Dadun meletakan "AlGhardul Aqsa Min Hayatil Muslim”, tujuan hidup muslim yang harus dicapai, yakni $A l$ Madinatul Munawwarah (dunia) dan AlJannatul Mau'udah Fil Akhirat (akhirat). Jika diringkas, maka sistematika Dinul Islam Ajengan Dadun terbagi kepada tiga bagian, pertama Al-Qur'an dan As-Sunnah sebagai landasan, kedua Iman, Islam, Ihsan dan $s a$ 'ah (waktu) sebagai alat, ketiga Jama'ah sebagai wadah. Semuanya bersinergi secara harmonis untuk mencapai tujuan akhir, yakni kebahagiaan hidup dunia dan akhirat. Konsep inilah yang tidak pernah dimunculkan oleh pemikir-pemikir Islam sebelumnya.

Meskipun memang sepintas usaha Ajengan Dadun dalam konteks pemurnian dan pelurusan ajaran Islam berbeda dengan ulama lain sehingga ada beberapa pihak yang menyamakannya dengan gerakan wahabi, namun jelas ada perbedaan, baik dalam tataran konseptual maupun pelaksanaannya. Terlebih Ajengan Dadun tidak pernah memasukkan

\footnotetext{
32 Wawancara dengan KH Nurdin Abdulqohhar, Minggu 25 November 2012.
} 
unsur-unsur pemaksaan dan kekerasan dalam setiap dakwahnya. Ajengan Dadun lebih memilih pendekatan halus dan melakukan dialog keilmuan yang disesuaikan dengan objeknya sehingga diharapkan timbulnya pemahaman baru nan utuh dalam diri mereka berdasarkan Al-Qur'an dan sunnah rasul.

Itulah konsep dan landasan pemikiran yang senantiasa dipegang teguh oleh Ajengan Dadun. Meski tantangan yang dihadapi selama berdakwah luar biasa berat, terutama pada masa-masa awal di mana terkadang beliau harus berjalan menuju lokasi pengajian berkilometer jauhnya pada malam hari melalui jalan persawahan yang sempit dan licin dengan penerangan seadanya, kemudian adanya pihak-pihak yang bersuara sumbang karena tidak menyukai kegiatan dakwahnya, hingga cobaan seperti bagaimana perjalanan menuju sebuah lokasi pengajian terhambat karena jalan yang akan dilalui dihalangi pohon besar yang sengaja ditumbangkan yang membuat beliau harus bersusah payah menyingkirkannya untuk kemudian melanjutkan perjalanan, pernah juga Ajengan Dadun dilempari batu dalam sebuah perjalanan menuju pengajian, serta berbagai cobaan lain. Namun tidak pernah sekalipun Ajengan Dadun berkomentar negatif, mengeluh apalagi melaporkan hal tersebut. Semua ujian itu diterima dengan tabah, tawakkal. Perlahan tapi pasti masyarakat pun menyadari dan menerima seruan dakwah tersebut. Kegiatan dakwah tersebut terus berlangsung secara konsisten hingga beliau tutup usia di tahun 2006 pada usia 83 tahun. ${ }^{33}$

Memang sangat disayangkan, karena Ajengan Dadun meninggal saat konsep pemikiran yang digagasnya belum mencapai tujuan, namun semua perjuangan yang telah dilakukan sangat dirasakan masyarakat. Karena itu tidak mengherankan ketika Ajengan Dadun meninggal, banyak pihak merasa kehilangan. Lautan jemaat yang terdiri

33 Wawancara dengan KH Muhammad, Jum'at 19 April 2013, pukul 18.30-20.00 WIB. dari ribuan manusia berbondong-bondong memadati kota Cibadak hingga jalanan pun mengalami kemacetan total sehari penuh dalam radius sekitar satu kilometer dari rumah duka, bahkan bupati Sukabumi serta beberapa tokoh kenamaan lain sampai harus turun dari mobil dan berjalan kaki berdesakan saking sesaknya jalanan pada saat itu. Fenomena ini seakan menjadi bukti nyata bahwa semasa hidupnya Ajengan Dadun merupakan muslim sejati yang sungguh-sungguh memperjuangkan Islam hingga hembusan nafasnya yang terakhir. ${ }^{34}$

Hanya saja, sepeninggalan Ajengan Dadun, konsep pemikiran brilian tersebut serta puluhan karya tulis meliputi buku, khutbah dan makalah yang merupakan warisan berharga bagi masyarakat seakan ikut terkubur seiring wafatnya beliau. Gaung nama Ajengan Dadun mungkin masih sangat disegani, namun warisan intelektualnya yang sangat berharga tidak benar-benar terangkat ke permukaan. Saat penulis mencoba mencari jawaban hal ini kepada K. Dudun Abdul Ghaffar, beliau berpandangan bahwa sebenarnya seluruh usaha dan perjuangan yang telah dilakukan Ajengan Dadun itu sudah sangat luar biasa, hasilnya pun dapat dirasakan secara nyata, namun jika ada yang harus "disalahkan", maka itu adalah ahli waris, yakni keluarga dan jamaa'ahnya yang tidak mampu meneruskan tongkat estafet perjuangan, entah karena keterbatasan kemampuan intelektual ataupun karena tidak ada seorang pun yang memiliki semangat juang sebesar Ajengan Dadun. ${ }^{35}$

\footnotetext{
34 Wawancara dengan KH Muhammad, Jum'at 19 April 2013, pukul 18.30-20.00 WIB. Pernyataan senada juga disampaikan oleh beberapa informan lain yang menyaksikan langsung kondisi saat itu ketika Ajengan Dadun meninggal, seperti Kang Ujang, tokoh pemuda desa Bungbulang tonggoh, uwa Adun, tokoh masyarakat sekaligus guru madrasah tempat penulis menimba ilmu dahulu dan salah satu murid pengajian mingguan Ajengan Dadun.

35 Wawancara dengan Dudun Abdul Ghoffar, ketua Yayasan Al-Basyriyyah Cicantayan, Minggu, 5 Mei, 2013.
} 
Pihak keluarga sendiri, yang diwakili KH. Nurdin Abdulqohhar, sebagaimana telah dijelaskan sebelumnya, mengakui bahwa belum ada sosok yang setara dan mampu menggantikan Ajengan Dadun. Dari sini penulis berpandangan bahwa penyebab utama ada beberapa faktor. Pertama, secara intelektual memang tidak ada sosok dalam keluarga dan murid-murid yang mempunyai kemampuan luar biasa seperti Ajengan Dadun sehingga tidak mampu meneruskan perjuangan yang telah dirintis. Kedua tidak ada penerus yang memiliki tekad, semangat juang dan keyakinan sekuat Ajengan Dadun. Indikasi paling terlihat adalah kondisi karya tulis Ajengan Dadun yang keberadaannya tidak terawat, malah banyak yang rusak karena tersimpan secara acak dan sembarangan. Memang ada karya tulis beliau yang masih dipakai saat ini di berbagai tempat, namun lebih banyak lagi karya tulis yang sepeninggalan ajengan dadun ikut terkubur dibawah tumpukan koran dan bukubuku lama. Aktifitas keilmuan pun tidak semarak seperti saat Ajengan Dadun masih ada, ini terlihat salah satunya dari bangunan asrama disamping masjid jami Ad-Da'wah yang saat ini terbengkalai karena tidak pernah digunakan. Terakhir, sebagian karya tulis Ajengan Dadun tidak diterbitkan dan diedarkan secara nasional, hanya terbatas dalam lingkup jama'ah, para guru dan penggiat da'wah sehingga masyarakat luas tidak mampu menikmati buah karya pemikiran Ajengan Dadun sepenuhnya.

\section{F. Kegiatan Dakwah dan Organisasi}

Sebagaimana lazimnya aktifitas para Ulama dan Da'i, keseharian Ajengan Dadun diisi dengan pengajaran Islam disertai kegiatan menulis. Telah disebutkan sebelumnya bahwa Ajengan Dadun sudah memulai aktifitas dakwah di usia yang sangat belia yakni pada umur 11 tahun, dimulai dengan memenuhi undangan pengajian, memberikan pengajaran kepada para pengajar di berbagai pesantren dan ceramah pada berbagai kegiatan keagamaan. Ajengan Dadun terkenal sebagai orator ulung yang lugas dan tegas hingga membuat namanya cepat terkenal ke mana-mana. ${ }^{36}$

Seiring berjalannya waktu, jangkauan dakwah Ajengan Dadun semakin meluas menyentuh semua kalangan, dari tingkat paling atas hingga level paling bawah. Sebelum hijrah ke wilayah Cibadak yang menjadi tempat tinggal saat ini, selama kurun waktu 1936 sampai tahun 1945, Ajengan Dadun aktif mengelola Pesantren Cantayan yang didirikan oleh ayahnya di samping rutin melakukan dakwah di berbagai tempat demi memenuhi panggilan masyarakat. Pada rentang waktu itu pula beliau aktif terlibat dalam organisasi Al-Ittihadul Islamiyyah (AII) yang didirikan oleh kakak tirinya, Ajengan Sanusi atau yang lebih dikenal dengan KH. Ahmad Sanusi. Kemudian pada tahun 1942 hingga tahun 1945 Ajengan Dadun turut aktif dalam organisasi Persatuan Ummat Islam Indonesia (PUII) sebagai pengganti AII di masa penjajahan Jepang.

Pada tahun 1949 Ajengan Dadun hijrah dari kampung halamannya Cantayan ke daerah Cibadak, perpindahan ini dilakukan karena pasca kemerdekaan daerah Cantayan menjadi ajang bentrok antara DI/TII kontra barisan Citarum aliran kiri sehingga menimbulkan kesulitan untuk melakukan kegiatan kemasyarakatan. ${ }^{37}$

Perpindahan ke daerah baru dengan tantangan yang samasekali berbeda tidak lantas membuat semangat juang mengendur, malah momentum ini seakan menjadi starting point yang baru bagi kegiatan dakwah Ajengan Dadun. Aktifitas rutin seperti

\footnotetext{
36 Wawancara dengan Dudun Abdul Ghoffar, ketua Yayasan Al-Basyriyyah Cicantayan, Minggu, 5 Mei, 2013

37 Biodata KH Dadun Abdulqohhar, Ketua Umum Yayasan Majlis Ta'lim Ad-Da'wah, Sesepuh Pesantren Ad-Da'wah Cibadak, Sukabumi, 1993, h. 9.
} 
ceramah dan majlis ta'lim terus berjalan. Beliau juga aktif dalam partai Masyumi antara tahun 1945 hingga 1960 dengan jabatan akhir sebagai wakil ketua wilayah Jawa Barat. Ajengan Dadun juga tercatat sebagai anggota aktif Persatuan Umat Islam (PUI) pada tahun 1945 hingga tahun 1964. Pada tahun 1957 Ajengan Dadun turut mendirikan Badan Musyawarah Ulama Militer Resimen 8 bersama kolonel Ishak Juarsa dengan sasaran utama penanggulangan keamanan, dan alhamdulillah cukup berhasil sehingga badan tersebut, atas prakarsa panglima Kodam Siliwangi saat itu yakni Mayor Jendral R.A. Kosasih, ditingkatkan menjadi badan dengan cakupan wilayah se-Jawa Barat, namanya pun dirubah menjadi Majlis Ulama Jawa Barat dan diresmikan pada Musyawarah Ulama Umara pada bulan September 1958. ${ }^{38}$

Selain berdakwah melalui berbagai organisasi kemsyarakatan, aspek pengajaran dan pendidikan yang menjadi concern utama juga tak luput dari peningkatan. Ditandai dengan didirikannya Yayasan Ad-Da'wah pada tahun 1964 dengan program utamanya berupaya mewujudkan tenaga kader yang berilmu dan berwawasan tinggi disamping berupaya menyumbang pola keilmuan mengenai Dinul Islam menurut apa yang diajarkan Allah melalui Rasulnya dengan mengikuti uswah Rasul dalam setiap pelaksanannya. Selain Yayasan Ad-Da'wah, Ajengan Dadun juga mendirikan lembaga pendidikan tinggi yang diberi nama Akademi Pembaru (Pembinaan Masyarakat Baru). Lembaga yang berlokasi di jalan Bhayangkara Sukabumi itu mendapat sambutan yang menggembirakan sehingga banyak calon mahasiswa yang saat itu tidak tertampung karena peminat yang membludak. Menurut penelusuran majalah GATRA, antusiasme masyarakat saat itu karena pada awal pendiriannya Akademi membuka kesempatan belajar secara gratis. Peminatnya membludak, mencapai ratusan orang, padahal, fasilitas

${ }^{38}$ Biodata KH Dadun Abdulqohhar, h. 9. ruangan terbatas. Maka, para siswa belajar di aula yang luas. ${ }^{39}$

Masih pada tahun yang sama, Ajengan Dadun kemudian mendirikan sebuah pesantren di wilayah Tegallega, Lembur Situ, Kecamatan Baros. Alhamdulillah usaha penyediaan lahan dan pembangunan prasarana pun berjalan lancar, sehingga pada tahun 1967 telah dibangun sebuah masjid, tiga rumah guru, satu asrama santri serta beberapa ribu meter tanah wakaf. Pengelolaan pesantren kemudian diserahkan kepada kakak dan adik beliau, yakni Ajengan Acun Mansur dan Ajengan Abdul Malik. ${ }^{40}$

Kemudian pada tahun 1965, secara terpisah Ajengan Dadun juga mendirikan Yayasan Da'wah dan lembaga pendidikan, juga dengan nama Akademi Pembaharu, di Jakarta. Lembaga ini didirikan karena Ajengan Dadun waktu itu dipercaya memegang sebuah komplek pendidikan yang berlokasi di Cawang bernama Madrasah Hayatul Islamiyyah (MHI) pimpinan $\mathrm{K}$. Dahlan. Ditengah derap perjuangan dakwah yang menunjukan perkembangan signifikan, Ajengan Dadun diterpa ujian cukup hebat hingga mengakibatkan pembubaran Akademi Pembaru. Sedikit sekali keterangan mengenai insiden ini. Pihak keluarga Ajengan Dadun pun enggan berkomentar banyak, mungkin membicarakan hal ini dianggap tabu karena bisa membuka luka lama serta sebagai bentuk penghormatan terhadap almarhum Ajengan Dadun yang sudah wafat. Hal ini sempat membuat penulis kesulitan, namun berdasarkan catatan pribadi dalam buku biografi Ajengan Dadun, dapat diketahui bahwa peristiwa tersebut diawali dengan terbitnya surat larangan untuk melakukan kegiatan di wilayah Sukabumi dari Komando Distrik Militer 0607 (kepolisian) Sukabumi terhadap Isa Bugis, seorang dosen akademi pembaru dan juga salah satu dewan petinggi

\footnotetext{
39 Majalah GATRA, Gerakan Pembaru Sang Ahli Tafsir, 6 Desember 2003.

${ }^{40}$ Biodata KH Dadun Abdulqohhar, h. 6.
} 
akademi, dikarenakan sikapnya yang kontroversial. ${ }^{41}$ Isa Bugis sendiri merupakan seorang tokoh yang sampai saat ini pun pemikirannya mengenai Al-Qur'an dan keislaman dianggap sesat oleh banyak kalangan.

Terbitnya surat larangan itu sendiri bermula dari keresahan masyarakat atas sepak terjang dakwah dan pemikiran Isa Bugis yang dianggap kontroversial. Pada awalnya, tidak ada yang janggal, tetapi dalam perkembangannya, ajaran Isa bugis kemudian dipandang aneh oleh sebagian ulama. Seperti dalam hal beribadah, mereka tak bisa ditawar. Walaupun mengaku terbuka dengan masyarakat umum, mereka tak menerima orang luar untuk menjadi imam salat mereka. Hal ini digambarkan dalam penelitian Afif H.M. pada buku Gerakan Islam Kontemporer di Indonesia (1989). Afif melihat orang di luar gerakan Isa Bugis dianggap belum sempurna benar keagamaannya. Karena itu, belum bisa memimpin salat. Kecuali kalau ia bergabung dengan aliran ini.

Selain itu, kaum Isa Bugis dituding menyepelekan Al-Quran. Berbagai cerita dalam Al-Quran, seperti kisah Nabi Musa dan Nabi Ibrahim, dipandang dongeng belaka. Seperti penafsiran Isa Bugis bahwa tongkat Nabi Musa yang membelah lautan itu bukan tongkat secara fisik, namun diartikan sebagai ilmu. Sangat rasional sekali. Pola pikir keislaman yang jauh berbeda dengan yang sudah ada inilah yang penulis rasa merupakan sumber keresahan masyarakat.

Karena itulah, belakangan para ulama saat itu memandang perkembangan ajaran Isa Bugis melenceng dari koridor Al-Quran dan hadis. Ajaran Isa Bugis sudah dianggap sesat. Rapat alim ulama Isam se-Sukabumi, 3 September 1968, memutuskan bahwa ajaran yang dibawa Isa Bugis adalah ajaran menyesatkan. Pernyataan ini juga mendapat sambutan dari berbagai organisasi Islam lainnya. Gerakan Isa Bugis mulai dikucilkan.

${ }^{41}$ Biodata KH Dadun Abdulqohhar, h. 6.
Bahkan, pada 17 Agustus 1968, salat Jumat di Desa Pesawahan, Kecamatan Cicurug, diulang ulama setempat. Pasalnya, salat Jumat itu dipimpin seorang pengikut Isa Bugis. ${ }^{42}$

Akibatnya, Komando Distrik Militer 0607 Sukabumi pun turun tangan. Mereka mengeluarkan surat keputusan melarang Isa Bugis berceramah di Sukabumi. Selain itu, Kepolisian Resor Sukabumi mengeluarkan larangan bagi mahasiswa Pembaru untuk berdakwa di wilayah Sukabumi. Larangan tersebut terbit ketika Ajengan Dadun yang menjabat sebagai pimpinan Biro Tabligh dan Dakwah akan mengadakan kegiatan upgrading di komplek Yayasan Ad-Da'wah dengan tujuan melatih dan menciptakan tenaga da'i atau muballigh. Saat itu acara seremonial pembukaan pelatihan diselenggarakan di gedung Bioskop Mayawati yang sekarang menjadi Capitol Sukabumi.

Saat itu Isa Bugis, melalui utusannya mengirim pesan agar kegiatan upgrading dibatalkan dan pembatalan itu harus diumumkan dengan alasan adanya larangan tersebut. Ajengan Dadun spontan menolak pembatalan pelatihan karena larangan tersebut tidak ada hubungannya dengan Akademi Pembaru, melainkan sebenarnya ditujukan kepada Isa Bugis pribadi. Seusai penolakan tersebut, Isa Bugis mengutarakan pemikiran dan pola keilmuan, yang entah isinya menyangkut arah kebijakan Akademi Pembaru atau menyangkut pemikiran keislaman, namun apa yang Isa Bugis utarakan tidak dapat diterima dan disetujui Ajengan Dadun sehingga timbul ketegangan antara kedua belah pihak.

Konflik ini kian memanas saat pihak Isa Bugis mengirimkan surat kepada Ajengan Dadun yang tembusannya ditujukan kepada pihak pejabat, termasuk bapak Anwari yang saat itu menjabat Danres kepolisian Sukabumi. Tidak ada keterangan detail mengenai isi dari surat tersebut, namun

${ }^{42}$ Majalah GATRA, Gerakan Pembaru Sang Ahli Tafsir, 6 Desember 2003. 
menurut keterangan KH Nurdin Abdulqohhar, surat tersebut secara garis besar berisi caci maki dan fitnah yang ditujukan kepada Ajengan Dadun. Sikap tersebut sangat tidak pantas dilakukan oleh Isa Bugis, sebagai seorang yang mengaku dirinya sebagai kampiun Al-Qur'an dan Sunnah. ${ }^{43}$

Ketegangan akibat perbedaan pendapat di antara dua petinggi ini sangat terasa, terlebih diluar pertentangan itu, kehebohan akibat kontroversi ajaran Isa Bugis sudah menarik perhatian Negara. Departemen Agama RI pun segera turun tangan. Mereka menurunkan peneliti dari Proyek Pengawasan Kegiatan Keagamaan dan AliranAliran/Faham-Faham.Amin Djamaluddin, peneliti aliran-aliran sesat dari Lembaga Penelitian dan Pengkajian Islam, juga dimintai pendapatnya. Apalagi, ternyata hasil penelitian itu cukup mengagetkan: gerakan Isa Bugis terpengaruh gerakan komunis internasional. "Itu bisa dilihat dari hubungan mereka dengan Partai Ba'ath di Irak," kata Amin kepada wartawan GATRA Rini Anggraini. Partai Ba'ath ketika itu baru saja berkuasa. Partai itu memang beraliran kekirikirian, yakni sosialis komunis. Nah, pendirian Pembaru, menurut Amin, sedikit banyak terilhami oleh Partai Ba'ath ini. Ba'ath bisa diartikan bangkitnya masyarakat baru. ${ }^{44}$

Akhirnya Akademi Pembaru Sukabumi dan Jakarta yang masih seumur jagung mengalami goncangan hebat dan terpaksa di bubarkan. Dengan dibubarkannya lembaga tersebut, Isa Bugis kembali ke Jakarta sementara Ajengan Dadun memfokuskan perhatiannya pada Yayasan Da'wah Cibadak yang bisa disebut sebagai pusat dari semua lembaga pendidikan yang telah didirikan sebelumnya. Pada tahun 1972 nama Yayasan dirubah menjadi Majlis Ta'lim Ad-Da'wah

43 Wawancara dengan KH Nurdin Abdulqohhar, Minggu 25 November 2012; lihat pula Biodata KH Dadun Abdulqohhar, h. 7.

${ }^{44}$ Majalah GATRA, Gerakan Pembaru Sang Ahli Tafsir, 6 Desember 2003. yang kemudian pada tahun 1978 diaktanotariskan dan tetap bertahan hingga sekarang. ${ }^{45}$

Diluar insiden diatas, salah satu hambatan Ajengan Dadun adalah persoalan manajerial. Ajengan Dadun tidak begitu paham dengan manajemen pendidikan modern dan manejemen pesantren, itulah sebabnya mengapa tidak banyak pesantren yang dibangun Ajengan Dadun. Pesantren yang sudah ada pun diserahkan pengurusannya kepada saudaranya. Kekurangan ini diakui oleh pihak keluarga, bahwa sebenarnya Ajengan Dadun ingin mendirikan lembaga pendidikan yang menjangkau semua jenjang kebutuhan masyarakat, terutama pendidikan Islam namun karena sedari remaja terbiasa mengajar para ustadz dan guru-guru pesantren dengan sistem pesantren murni, bukan mengajar santri maka pendidikan formal dan modern dirasa merepotkan karena harus selalu berurusan dengan pemerintah. Ajengan Dadun pernah mendirikan PGA, Aliyah-Tsanawiyah dan SMPIT, namun karena tidak terlalu mengenal manajemen pendidikan modern, akhirnya bubar. ${ }^{46}$

Oleh karena basic dan kecendrungan Ajengan Dadun adalah pesantren murni, maka beliau kemudian menyalurkan ide dan hasratnya melalui Ma'had 'Aly. Khusus untuk Ma'had Aly, Ajengan Dadun mengukir prestasi yang membangggakan, karena beliau merupakan penggagas pertama pendirian Ma'had 'Aly di Jawa Barat. Konsep mengenai Ma'had Aly ini diterbitkan ketika beliau menjabat sebagai wakil ketua BKSPP Jabar (Badan Kerjasama Pondok Pesantren Jawa Barat).

\section{G. Karya Tulis yang dihasilkan}

45 Biodata KH Dadun Abdulqohhar, h. 7; lihat pula Anna Mariana, Pengaruh Khitobah KH Dadun Abdulqohhar dalam Meningkatkan Pemahaman Keagamaan Masyarakat (penelitian di Majlis Ta'lim Ad-Da'wah Cibadak Sukabumi), h. 47.

46 Wawancara dengan KH Nurdin Abdulqohhar, Minggu 25 November 2012. 
Di samping bangunan fisik berupa komplek Yayasan majlis ta'lim Ad-Da'wah beserta unit-unit yang tersebar di berbagai wilayah di Jawa Barat, warisan Ajengan Dadun yang paling berharga adalah karya tulis. ${ }^{47}$ Selain dikenal luas sebagai ulamaintelektual yang karismatis, Ajengan Dadun juga merupakan penulis yang produktif, terutama dalam bidang aqidah dan tafsir yang menjadi spesialisasi beliau. Produktifitasnya dibuktikan dengan karya tulis (meliputi buku, makalah, khutbah, diktat, termasuk juga yang masih berupa konsep pemikiran dengan tulisan tangan) yang berjumlah puluhan judul dengan meliputi berbagai disiplin ilmu. Berikut adalah daftar karya tulis disertai dengan penjelasan singkat mengenai isi kandungannya:

\section{Wawasan Utuh Tentang Dinul Islam \\ Buku ini merupakan karya tulis Ajengan} Dadun yang dapat dikatakan merupakan himpunan dari beberapa makalah dan tulisan singkat mengenai konsep Dinul Islam yang sudah ada sebelumnya. Dalam pengantarnya, Ajengan Dadun menyebut bahwa penerbitan buku ini merupakan usaha untuk menjelaskan Islam dengan wawasan Qur'ani. Isi buku diawali dengan muqaddimah sebanyak 27 halaman berisi ayat-ayat Al-Qur'an dan Hadist yang menjelaskan mengenai Islam, dilanjutkan dengan penjelasan isi pokok kandungan Alqur'an dan Assunnah, tiga unsur

47 Selama proses penulisan, penulis juga diberi tugas untuk menginventarisir ulang, mendata dan mendokumentasikasn karya tulis Ajengan Dadun yang dapat dibilang tidak terpelihara dengan baik, seperti ada beberapa naskah ketikan yang hilang sebagian, beberapa buku yang lusuh dan hampir rusak karena terkena lembab dan air hujan, dan beberapa ketikan khutbah yang berceceran di beberapa tempat. Pada saat tulisan ini telah memasuki tahap akhir, penulis ditunjuk menjadi tim penyusun ulang untuk merancang dan menerbitkan kembali seluruh karya tulis Ajengan Dadun yang direncanakan terdiri dari lima jilid, masing-masing di bawah tema Dienul Islam, Tafsir AlQur'an, Hadits dan Atsar Sahabat, Kumpulan Khutbah serta Pemikiran dan Makalah Ilmiah.
Dinul Islam yakni Iman, Islam dan Ihsan, fungsi Dinul Islam, kemudian menjelaskan tujuan hidup muslim dan diakhiri dengan pembahasan jama'ah sebagai wadah untuk mencapai tujuan. Ini adalah salah satu karya Ajengan Dadun paling komprehensif mengenai konsep Dinul Islam yang banyak dijadikan buku pegangan para juru dakwah, guru-guru dan asatidz. Buku ini diterbitkan pada tahun 1993 oleh Yayasan Majlis Ta'lim Ad-Da'wah.

\section{Muslimkah saya?}

Masih terkait dengan konsep pemikiran Dinul Islam. Seperti buku Wawasan Utuh Mengenai Dinul Islam di atas, buku ini ini berasal dari diktat yang telah ditulis Ajengan Dadun pada tahun 1978 yang kemudian di bukukan pada tahun 1990 oleh Yayasan Majlis Ta'lim Ad-Da'wah. Secara garis besar isi buku tetap membahas sistematika Dinul Islam. Pembahasan dimulai dengan sorotan terhadap problematika umat Islam saat itu, kemudian dilanjutkan dengan penjelasan Dinul Islam sebagai solusi. Bagia penutup di isi dengan pembahasan bernuansa kontemplatif yang berusaha mengajak pembaca untuk introspeksi diri, sejauh mana pemahaman kita terhadap Islam, sedalam apa pemahaman kita terhadap kehidupan dan tujuan kita dalam hidup ini.

\section{Majmu'atul Asy'ar}

Judul lengkapnya adalah Majmu'atul asy'ar, Kumpulan Syir'ir Berisi Nasehat dan Petunjuk Hidup. Diterbitkan oleh Yayasan Majlis Ta'lim Ad-Da'wah pada tahun 1992. Sesuai dengan judulnya, buku ini berisikan sya'ir dan kata-kata bijak tentang kehidupan. Diantaranya adalah nasehat untuk tidak terlena dengan kehidupan dunia, bahay mengejar harta kekayaan, petuah

untuk memelihara sikap, anjuran untuk memperbanyak silaturahmi, penting menekan hawa nafsu, keharusan untuk menyukuri nikmat dan masih banyak lagi petuah yang 
jumlahnya ada 100 syi'ir. Salah satu sya'ir tentang hawa nafsu berbunyi sebagai berikut, "sesungguhnya hawan (kehinaan) adalah dari kata Hawa (hawa nafsu) yang ditukar sebutannya. Karena itu apabila anda mengikuti hawa nafsu maka pasti anda akan menemukan kehinaan". Salah satu sya'ir lain mengenai perumpamaan orang yang hanya mengejar kehidupan dunia, "aku melihat orang yang hidupnya semata-mata mengejar materi sekalipun usainya pajang dan hidupnya mewah, tidak berbeda dengan yang membangun bangunan yang kokoh-kuat, namun setelah bangunan itu selesai dibangun dirobohkannya".

\section{Gerhana Matahari Total, Dilengkapi Petunjuk Shalat Gerhana \\ Buku ini ditulis Ajengan Dadun bersama} KH. Tangsoban dan KH. Bahrum Efendi yang diterbitkan pada tahun 1988 oleh Lembaga Pengembangan Ilmu Hisab, Falaq dan Faraidh Pondok Pesantren. Penerbitan buku ini selain dilakukan untuk menyongsong terjadinya fenomena gerhana matahari total pada tanggal 18 maret 1988, juga menunjukan bahwa ada ahli-

ahli hisab dan di lingkungan pesantren Sukabumi yang senantiasa mengamati perputaran bulan dan matahari untuk dapat mengetahui fenomena alam seperti gerhana sehingga umat Islam bisa mengetahuinya dengan jelas.

Dalam buku ini dimuat penjelasan mengenai gerhana matahari, proses terjadinya serta cara pengamatan dan penghitungan waktu terjadinya gerhana, bagian terakhir di isi dengan tata cara shalat dan khutbah gerhana.

5.Merokok Menurut Hukum Islam

Buku ini merupakan saduran dari beberapa bagian kitab "Yasaluunaka Fiddini Wal Hayat" karya DR. Ahmad Asy-Syarbasyi dan kitab "Al-Fatawa" karya Imam Mahmud Syaltut seputar dunia rokok, dampak dan bahayanya serta pandangan hukumya. Buku yang diterbitkan pada tahun 1994 oleh Yayasan Ad-Da'wah ini berawal dari keprihatinan Ajengan Dadun terhadap budaya merokok yang saat itu kian marak, padahal selain membawa pengaruh buruk bagi kesehatan, merokok juga dipandang sebagai israf (mempergunakan harta secara berlebihan untuk hal yang tidak bermanfaat).

\section{Tafsir Al-Qur'anul Hakim “Ad-Da'wah" \\ Buku tafsir Al-Qur'an ini merupakan} wujud kecintaan dan perhatian besar Ajengan Dadun terhadap upaya untuk menelaah dan pengkajian Al-Qur'an lebih dalam sebagai sumber hukum tertinggi yang harus menjadi pedoman dalam kehidupan manusia. Upaya ini di awali dengan penerbitan Tafsir Surat AlFatihah, kemudian dilanjutkan dengan seri Tafsir Al-Qur'anul Hakim juz 30 yang terbit secara terpisah menjadi beberapa edisi. Salah satunya Tafsir Al-Qur'anul Hakim juz 30 edisi surat Al-Lail, Adl-Dluha dan Al-Insyirah yang terbit pada tahun 1993, edisi surat At-Tahrim yang ditemukan tanpa tahun, Pemilihan juz 30 sebagai langkah pertama dikarenakan suratsurat pendek yang ada di dalamnya merupakan khulashah (kesimpulan) dari suratsurat panjang (Madanniyyah). Perbedaan tafsir Al-Qura'an karya Ajengan Dadun dengan tafsir lain adalah pada bagian penjelasan. Setelah diartikan ayat demi ayat, diakhir surat diberikan penjelasan yang lebih luas, lebih mendalam, penggunaan bahasa yang lugas namun tidak mengubah isi kandungan ayat sekaligus membuatnya lebih mudah difahami serta penggunaan ayat-ayat dari surat lain sebagai bukti penguat sekaligus menunjukan bahwa setiap ayat, bahkan setiap kata dalam Al-Qur'an memiliki keterkaitan satu sama lain.

Buku tafsir ini merupakan salah satu karya tulis Ajengan Dadun yang banyak dipakai para muballigh, guru-guru madrasah, dan pengajian-pengajian. Disamping sejumlah karya tulis diatas, untuk lebih mempermudah, hasil penelusuran lain yang didapat selama 
proses pengumpulan penulis cantumkan dalam bentuk daftar tulisan berdasarkan disiplin ilmu:

\section{a) Aqidah/ Dinul Islam}

Daftar pertama yang penulis cantumkan adalah karya tulis yang meliputi displin ilmu aqidah sebagai spesialisasi Ajengan Dadun, terutama melalui konsep pemikiran Dinul Islam yang menjadi ciri khasnya. Berikut adalah daftar karya tulisnya:

1. Menuju Islam Kaffah, 2000. Makalah mengenai Dinul Islam yang menjelaskan proses menuju Islam yang kaffah, diantaranya dengan mengenal hakekat manusia dan Mengenali Qalbu.

2. Karakteristik Dinul Islam, tanpa tahun. Merupakan makalah singkat yang secara isi materi menjelaskan karakter Dinul Islam yang meliputi Ar-Rabbaniyyah, AlInsaniyyah, As-Syumul, Al-Wasyitiyah, AlWaqiyyah, Al-Wadhih, dan Al-Jam'u Baina Tsabt wa Tathawur

3. Kumpulan Makalah Seputar Dinul Islam, Arkanul Islam, Iman dan Al-Qur'an, 1990 (tidak lengkap, 20 halaman pertama hilang)

4. Wawasan Integral Tentang Dinul Islam, tanpa tahun.

5. Sistematika Dinul Islam, tanpa tahun.

6. Uraian Singkat Mengenai Dinul Islam, tanpa tahun.

7. Arkanul Islam dan Prinsip-Prinsip Akhlak, 1994.

8. Makalah Singkat Dinul Islam, tanpa tahun (lembar pertama hilang).

Tulisan Wawasan Integral Tentang Dinul Islam merupakan diktat yang menjadi bahan penulisan buku Wawasan Utuh Tentang Dinul Islam, sementara Sistematika Dinul Islam, Uraian Singkat Mengenai Dinul Islam, Arkanul Islam dan Prinsip-Prinsip Akhlak, 1994 hingga makalah singkat tentang Dinul Islam merupakan makalah singkat yang dasarnya diambil dari tulisan mengenai Dinul Islam yang sudah ada.
9. Materi Dinul Islam Untuk Pasca TKA, TPA, TQA, Madrasah Diniyah dan Remaja Islam. Merupakan buku pegangan untuk anak-anak yang diterbitkan tahun 1414 $\mathrm{H}$ oleh Yayasan Majlis Ta'lim AdDa'wah berisi wawasan mengenai sistematika Dinul Islam yang dikemas dalam bentuk Tanya-jawab agar lebih mudah dipahami.

b) Al-Qur'an dan Tafsir

1. Materi Ulumul Qur'an Pasca TKA/TPA, (seri Ta'limul Qur'an Lil Aulad), diterbitkan oleh restu offset, tahun $1414 \mathrm{H}$. berisi nama-nama surat, nama Al-Qur'an yang ditujukan supaya anak-anak dapat mengenal AlQur'an sejak dini.

2. Kumpulan Materi Terjemah Hapalan TKA/TPA Untuk Pasca TKA/TPA, (seri Ta'limul Qur'an Lil Aulad), berisi materi hafala surat-surat pendek bagi pelajar TKA dan TPA.

3. Buku Panduan Program Pasca TKA/TPA, (seri Ta'limul Qur'an Lil Aulad), 1414 H 4.

4. Materi Hafalan Al-Mahfudzot, (seri Ta'limul Qur'an Lil Aulad), berisi kata-kata bijak mengenai sikap mulia, keutamaan ilmu, amal perbuatan, keutamaan akhlaq dan lain-lain yang ditujukan bagi pelajar anak-anak.

5. Terjemah Lafdhiyyah Tafsiriyyah, 1993.

6. Materi Terjemah Lafdhiyyah, Sistim Tartibiyyah (khusus pegangan para ustadz), (seri Ta'limul Qur'an Lil Aulad)

7. Kunci Materi Terjemah Lafdhiyyah, Sistim Tartibiyyah (khusus pegangan para ustadz), (seri Ta'limul Qur'an Lil Aulad)

Semua buku seri Ta'limul Qur'an Lil Aulad merupakan buku karya Ajengan Dadun yang bekerjasama dengan team tadarrus AMM 
As'ad Humam (penemu metode Iqra) Yogyakarta dan dijadikan buku ajar standar di berbagai lembaga pendidikan TK/TPA/TQA/TKQ di berbagai sekolah, salah satunya di TK tempat penulis belajar pada masa kecil. ${ }^{48}$

8. Tafsir surat Al-Lail dan Ad-Dhuha, tanpa tahun.

9. Tanya Jawab Seputar Al-Qur'an, 1996.

10. Al-Quran dan Akal Manusia, tanpa tahun (naskah dibagian terakhir telah hilang).

11. Makalah Metode Pengkajian Al-Qur'an, Cibadak 20 Desember 1990.

c) Ibadah (Pembinaan Iman)

1. Tuntunan Shalat Praktis (Untuk Pasca TKA/TPA/MD/Remaja Islam dan Masyarakat Muslim Pada Umumnya). Diedarkan dalam rangka memberikan wawasan seputar tatacara shalat secara bagi seluruh masyarakat.

2. Tuntunan Shaum Ramadhan, 1999.

3. Tuntunan Haji, Bahasa Sunda, tanpa tahun.

4. Penjelasan Ringkas Tuntunan Shalat, 1984.

5. Ahkaamul janaiz, Pedoman Ringkas Pengurusan Jenazah Secara Islami, 1994.

6. Tuntunan haji, Sumbang Pikiran Dalam Rangka Meluruskan Pandangan Tentang Haji Serta Sikap Dan Konsekuensi Pelaksanaan Haji, 2001.

7. Tuntunan haji, tanpa tahun

8. Kullu Nafsin Dzaaiqotul Maut, Pedoman Pengurusan Jenazah Menurut Ajaran Islam.

d) Sejarah (Tarikh)

Dzikra Hijraturrasul Muhammad SAW Min Makkah Ilal Madinah, Tela'ah Tentang Hijrah Nabi Muhammad SAW, tanpa tahun.

e) Hadits

1. Hadits- Hadits Pilihan, Al-Muhktar Minal Mukhtar, Bab Ilmu, 1993. Berisi hadits-

${ }^{48}$ Lebih tepatnya di TKA (taman kanak-kanak Al-Qur'an) Ad-Da'wah Nurul Huda, yang berlokasi di kampung Bungbulang, desa Cijengkol, Kecamatan Caringin, Sukabumi. hadits yang diseleksi Ajengan Dadun yang berkaitan dengan ilmu.

2. Pelajaran Hadits Nabi dan Atsar Sahabat, tanpa tahun.

3. Al-Ahaadits An-Nabawiyyah Fi Asyrati AsSaa'ah, Beberapa Hadits Nabi Mengenai Sa'ah.

f) Buku Kumpulan Khutbah:

Buku khutbah yang bisa teridentifikasi adalah sebagai berikut:

1. Khutbah Idul Fitri, sebanyak Sembilan buah, dengan rincian khutbah Idul Fitri tahun 1401, 1405, 1408, 1411, 1412, 1413, dan 1415 H. Serta dua buku khutbah tanpa tahun.

2. Khutbah idul Adha, sebanyak sembilan buah, dengan rincian khutbah Idul Adha tahun 1404, 1406, 1408, 1410, 1411, 1413, 1414, 1415, dan $1421 \mathrm{H}$.

3. Enam Judul Khutbah yang merupakan bagian dari serial Khutbah Jum'at dari tahun $1400 \mathrm{H}-1402 \mathrm{H}$.

4. Buku kumpulan Khutbah Jum'at bahasa Sunda (yang berhasil diselamatkan adalah dari Khutbah ke 26 karena kerusakan pada dokumen)

5. Khutbah Nikah, Bimbingan Bagi Calon Mempelai. Sesuai dengan namanya, buku ini diterbitkan khusus sebagai panduan bagi mereka yang mulai membangun rumah tangga supaya tercipta keluarga yang harmonis dan sakinah.

g) Makalah dan Dokumen Lain

1. Menjemput Ramadhan Sebagai Bulan Shaum dan Bulan Al-Qur'an, dokumentasi PP 'Ibadurrahman YLPI Tegallega Sukabumi.

2. Al-Qur'an dan Rasulullah Muhammad SAW Memberi Petunjuk Dasar Penanggalan, 1986.

3. Pengertian dan Strategi Dakwah, tanpa tahun.

4. Peran Ulama dalam Pembangunan, Disampaikan Bagi Peserta Diklatram 
Pon-Pes Tingkat Regional di Jawa Barat, tanpa tahun.

5. Bagaimana Sikap dan Tindakan Umat Islam Terhadap Narkoba dan Napza, tanpa tahun.

6. Profil, Sebuah Sumbang Fikir Qur'ani Tentang Negara dan Kepemimpinan, tanpa tahun.

7. Harta Kekayaan, Fungsi dan Pemanfaatan, $1418 \mathrm{H}$

8. Kedudukan Al-Qur'an dan As-Sunnah, tanpa tahun (dokumen tidak lengkap, hanya bagian ke -6 hingga akhir yang dapat teridentifikasi)

9. Biodata KH Dadun Abdulqohhar, Ketua Umum Yayasan Majlis Ta'lim Ad-Da'wah, Sesepuh Pesantren AdDa'wah Cibadak, Sukabumi, 1993.

10. Risalah Islam, Kumpulan Catatan Pengajian Ajengan Dadun Di Majlis Ta'lim PGRI Cabang Kecamatan Sukmajaya, Bogor Periode 1986-1989.

11. Buku Doa Khusus untuk Orang Sakit, Bagi Pasien Rumah Sakit Islam Assyifa Sukabumi, tanpa tahun.

12. Terapi Qolbu di Kala Sendu, buku pegangan terapi spiritual bagi pasien di rumah sakit Islam Assyifa Sukabumi, tanpa tahun.

13. Renungan Bulan Suci Ramadhan, 1405 H.

14. Jamaah, Imamah dan Baeat Adalah Syare'at Islam Berdasar Alqur'an dan AsSunnah, tanpa tahun.

15. Panduan Praktis untuk Imam dan Khatib, tanpa tahun.

16. Buku berisi tulisan tangan Ajengan Dadun Abdulqohhar yang berisi tulisan tentang hukum, aqidah, fiqih, dan pemikiran beliau mengenai Islam berbahasa Sunda dengan huruf Arab pegon, tanpa tahun.

17. Bekal Para Pembina Akhlak Dari Ungkapan Para Bijak, tanpa tahun.

18. Usaha Kaderisasi Ulama, 1986.

19. Sejarah Perjalanan Syari'at Islam, tanpa tahun.
20. Konsep Islamisasi Industri, tanpa tahun.

21. Konsep Pembinaan Aparatur Pemda Kabupaten Sukabumi.

22. Konsep Penegakan Syari'at Islam di Kabupaten Sukabumi.

23. Konsep Ma'had Ali, Kurikulum dan Silabusnya.

24. Kumpulan materi pengajian kaum ibu dan kaum bapak.

25. Proses Penciptaan Manusia, tanpa tahun.

\section{H. Generasi Penerus dan Murid-Muridnya}

Sebagai seorang pejuang Islam yang konsisten melakukan dakwah serta pengajaran keagamaan, banyak orang yang telah menimba ilmu dari beliau melalui majlis ta'lim, pengajian mingguan dan kegiatan pengajaran lain. Banyak pula dari mereka telah meraih sukses baik sebagai tokoh intelektual maupun tokoh keagamaan. Sesuai dari keterangan yang diperoleh dari $\mathrm{KH}$. Nurdin, beberapa dari mereka yang cukup terkemuka adalah: ${ }^{49}$

1. KH. Didin Hafiduddin 5.A.M Saipudin

2. KH. Miftahul Farid

6. $\mathrm{M}$

Dawam Raharjo

3. KH. E Zainal Abidin 7. Hidayat Nur Wahid

4. KH. Khalil Ridwan $8 . \quad \mathrm{KH}$.

Roja (pemilik stasiun Roja' TV)

Selain nama-nama di atas, mereka yang juga pernah menjadi murid Ajengan Dadun adalah para pejabat (aktif maupun pensiunan) di Kabupaten Sukabumi, tiga generasi Bupati Sukabumi termasuk yang sekarang masih menjabat, yakni H. Sukmawijaya, serta sejumlah pendiri dan pengasuh Pondok Pesantren di wilayah Sukabumi, Bogor, Banten dan Cianjur. ${ }^{50}$

\footnotetext{
49 Wawancara dengan KH Nurdin Abdulqohhar, Direktur KPA Ad-Da'wah Cibadak, Minggu 25 November 2012. 50 Wawancara dengan KH Muhammad, Jum'at 19 April 2013, pukul 18.30-20.00 WIB.
} 
Mereka inilah, yang meskipun tidak pernah belajar dalam kurun waktu yang bersamaan dan mungkin tidak pernah mengenal langsung satu sama lain, namun semuanya mewarisi nafas intelektual yang sama serta menjadi penerus semangat dan cita-cita perjuangan Ajengan Dadun dalam membina umat menuju terciptanya kehidupan masyarakat Islam yang sejalan dengan AlQur'an dan As-Sunnah.

\section{PENUTUP}

Ajengan Dadun, yang terlahir dari keluarga pejuang dan ulama terpandang di Sukabumi, merupakan sosok ulama besar yang pengaruhnya diakui oleh masyarakat luas, terutama dalam aspek pendidikan dan pengembangan umat. Hal ini dapat dibuktikan melalui puluhan lembaga pendidikan yang ditinggalkan, karya tulisnya yang hingga saat ini masih dipakai di berbagai lembaga pendidikan, murid-murid yang banyak meraih kesuksesan, kontribusinya dalam perjuangan kemerdekaan, serta sumbangsih tenaga dan pemikiran dalam berbagai organisasi dan kegiatan politik.

Kontribusi Ajengan Dadun dalam memajukan Islam di Sukabumi cukup besar, karena mampu memberikan sumbangsih nyata. Dalam aspek pendidikan, Ajengan Dadun telah melakukan kegiatan pengajaran sejak usia 11 tahun melalui dakwah, ceramah dan mengisi pengajian di berbagai tempat. Kemudian dengan dibangunnya berbagai sarana dan lembaga pendidikan seperti pesantren dan Yayasan Majlis Ta'lim AdDa'wah yang membawahi banyak lembaga pendidikan yang berorientasi kepada peningkatan dan pengembangan Islammasyarakat berdampak pada kondisi masyarakat yang tadinya tidak terlalu faham tentang agama menjadi lebih berwawasan. Tradisi dan kebiasaan yang menjurus kepada kemusyrikan yang sebelum kedatangan Ajengan Dadun lekat di kehidupan masyarakat perlahan hilang diganti dengan tradisi yang lebih islami. Ajengan Dadun juga tercatat sebagai penggagas pendirian Ma'had Aly di Jawa Barat. Konsep dan gagasannya kemudian menjadi acuan bagi silabus dan pendirian Ma'had Aly di berbagai tempat.

Dalam aspek perjuangan kemerdekaan melawan penjajah, ajengan dadun aktif berkontribusi dalam perjuangan fisik bangsa Indonesia melawan penjajah, dimulai dengan menjadi anggota BII (Barisan Islam Indonesia) yang merupakan organisasi kader AII (Al-Ittihdul Islamiyyah), hingga menjadi anggota laskar Hizbullah Sukabumi serta mendirikan Pasukan Rakyat Sukabumi. Selain itu bersama kolonel Ishak Juarsa, Ajengan Dadun tercatat sebagai pendiri Badan Musyawarah Ulama Militer Resimen 8, sebuah badan keamanan yang kemudian ditingkatkan menjadi Majlis Ulama Jawa Barat dan diresmikan pada Musyawarah Ulama Umara pada bulan September 1958. Jasa-jasa Ajengan Dadun diakui oleh Negara berbagai penghargaan yang diberikan secara resmi kepada Ajengan Dadun. Selain itu, banyaknya murid Ajengan Dadun yang menjadi tokoh penting menjadi bukti tak terbantahkan atas kontribusi Ajengan Dadun dalam dunia dakwah, pendidikan dan pengembangan masyarakat.

Dalam interaksi keseharian, Ajengan Dadun merupakan sosok tegas namun sangat menyayangi keluarga, ramah dan mudah bergaul dengan semua golongan masyarakat. Ajengan Dadun selalu menganggap seluruh murid pengajian sebagai sahabat dan keluarga. Begitu besarnya perhatian Ajengan Dadun kepada mereka sehingga seringkali Ajengan Dadun memberikan bantuan moral atau material jika memang di antara mereka ada yang mengalami kesulitan. Sikap mulia tersebut sekarang sudah mulai jarang ditemui. Karena itu, hubungan guru murid yang diperlihatkan Ajengan Dadun patut dijadikan cermin sejarah bagi semua penggiat pendidikan. Meski pada masa awal dakwah seringkali mendapat tentangan serta rintangan, 
baik fisik maupun psikis dari banyak pihak, hal tersebut tidak sedikitpun membuat semangat dakwahnya mengendur. Ajengan Dadun tetap konsisten berdakwah hingga menghembuskan nafas terakhir pada tahun 2006 di usia 83 tahun.

\section{IV.DAFTAR PUSTAKA}

\section{Sumber Primer}

Biodata KH Dadun Abdulqohhar, Ketua Umum Yayasan Majlis Ta'lim Ad-Da'wah, Sesepuh Pesantren AdDa'wah Cibadak, Sukabumi, 1993.

Bulletin Adz-Dzurriyyat, Edsisi Perdana, 2005.

Dokumen Silsilah keluarga Ama KH. Abdurrahim, Pusat Informasi Keluarga (PIK), Pesantren Putri Tarbiyatun Nisaa, Rancabungur, Bogor.

\section{Sumber Sekunder}

Abdullah, Taufik, dkk, ed. Manusia dalam Kemelut Sejarah, Jakarta: LP3ES, 1983.

Anwar, Rosiehan. Ulama dalam Penyebaran Pendidikan dan Khazanah Keagamaan, Jakarta: Proyek Pengkajian dan Pengembagan Lektur Pendidikan Agama,

Badan Litbang Agama dan Diklat Keagamaan Departemen Agama RI, 2003.

Benda, Harry J. Bulan Sabit dan Matahari Terbit, Islam Indonesia pada Masa Pendudukan Jepang, Terj. Dhaniel Dhakidae, Jakarta: Pustaka Jaya, 1980.
Dhofier, Zamaksyari. Tradisi Pesantren: Studi Tentang Pandangan Hidup Kyai, Jakarta: LP3ES, 1982.

Dudung, Abdurahman. Metodologi Penelitian Sejarah, Jakarta: Ar-Ruzz Media, 2007.

Falah, Miftahul. Riwayat Perjuangan KH Ahmad Sanusi, Sukabumi: Masyarakat Sejarah Indonesia (MSI) Cabang Jawa Barat, 2009.

George McTurnan Kahin, Nasionalisme dan Revolusi di Indonesia, Sebelas Maret University Press dan Pustaka Sinar Harapan, 1995.

Hariyono.Mempelajari Sejarah Secara Efektif, Yogyakarta: Pustaka Jaya, 1995.

Isnaeni, Hendri F. \& Apid, Romusa, Sejarah yang Terlupakan, Yogyakarta: Dua Mata Air, 2008.

Jaya, Ruyatna. Sejarah Sukabumi, Sukabumi: Yayasan Pendidikan Islam, 2002.

Kartodirjo, Sartono. Pendekatan Ilmu Sosial dalam Metodolgi Penelitian Sejarah, Jakarta: Gramedia, 1992.

Koentjaraningrat. ed. MetodeMetode Penelitian Masyarakat, Jakarta: Gramedia, 1979.

- Manusia dan Kebudayaan di Indonesia, Penerbit Djambatan: Jakarta, 1979. 
Kosoh. S dan Suwarno, Sejarah Daerah Jawa Barat, Proyek Inventarisasi dan Dokumentasi Sejarah Nasional, Jakarta, 1994.

Munir, M, Wahyu Ilahi, Manajemen Dakwah, Kencana, Jakarta: 2009

Moedjanto, G, Indonesia Abad Ke-20; Dari Kebangkitan Nasional sampai Linggarjati, Yogyakarta: Kanisius, 1993.

Munir, Syamsul. Ilmu Dakwah, Jakarta: Penerbit Amzah, 2009.

\section{Muzayin, Arifin. Pendidikan Islam dalam Arus Dinamika Masyarakat, Jakarta: Golden Trayon, 1988.}

Noer, Deliar. Gerakan Modern Islam di Indonesia 1900-1942, Jakarta: LP3ES, 1991.

Sanafiah, Faisal, ed. Metodologi Penelitian Kualitatif, Surabaya: Usaha Nasional, 1987

Shihab, Quraish. Membumikan AlQur'an, Fungsi dan Peran Wahyu Dalam Kehidupan Masyarakat, cetakan 22, Bandung: Mizan, 2001.

Soekanto, Soerjono. Sosiologi Suatu Pengantar, Edisi Baru, Jakarta: CV. Rajawali, 1982.

Sukamto,. Kepemimpinan Kyai dalam Pesantren, Jakarta: LP3ES, 1999.

Suprayogo, Imam. Kyai dan Politik, Membaca Citra Politik Kyai, UIN-Malang Press, 2009.
Supyaratno, Suparlan. Kapita Selekta Pondok Pesantren, Jakarta: Paryu Berkah 1976.

\section{Jurnal, Ebook, Majalah}

Buku Statistik Daerah Kota Sukabumi 2012, Badan Pusat Statistik (BPS) Kota Sukabumi.

Rencana Pembangunan Jangka Menengah Daerah (RPJMD) Kota Sukabumi Tahun 2008-2013, Badan Pusat Statistik (BPS) Kota Sukabumi.

Majalah GATRA, Gerakan Pembaru Sang Ahli Tafsir, 6 Desember 2003.

\section{Media Online}

(www.sukabumikota.go.id/detailb erita.asp?id=) Situs resmi Pemerintah Kabupaten Sukabumi. Diakses pada pukul 10.35 WIB, tanggal 21 Desember 2012.

(http://etnohistori.org/tak-adarotan-akar-pun-jadi-kisah-gedunginspektorat-sukabumi.html) "Tak Ada Rotan, Akar Pun Jadi" (Kisah Gedung Inspektorat Sukabumi), Anna Mariana. Diakses pada 17 Desember 2012.

\section{Skripsi dan Hasil Penelitian}

Ahmad Sofwan Hilmi, $K H$ Muhajirin Amsar Addary dan Peranannya Terhadap Perkembangan Islam di Bekasi, Skripsi Sejarah dan Peradaban Islam, UIN Syarif Hidayatullah Jakarta, 2013.

Anna Mariana, Pengaruh Khitobah KH Dadun Abdulqohhar dalam Meningkatkan Pemahaman Keagamaan Masyarakat (Penelitian di Majlis Ta'lim Ad-Da'wah Cibadak 
Sukabumi). Skripsi Komunikasi Penyiaran Islam, UIN Sunan Gunung Djati Bandung, 2005.

Muhsin Fadhli, Peran Da'wah Kyai Haji Dadun Abdulqohhar dalam Membina Masyarakat CibadakSukabumi. Skripsi Komunikasi Penyiaran Islam, STID Mohammad Natsir Jakarta, 2012.

Siti Fatimah, Peranan $K H$ Muhammad Cholil dalam Mengembangkan Islam di BangkalanMadura. Skripsi Sejarah dan Peradaban Islam Fakultas Adab dan Humaniora, UIN Syarif Hidayatullah Jakarta, 2011.

Titin Farhatin, Islam Sukabumi Pada Masa Penjajahan Jepang. Skripsi Jurusan Sejarah dan Peradaban Islam Fakultas Adab dan Humaniora, UIN Syarif Hidayatullah, Jakarta, 2005.

\section{Wawancara}

Wawancara dengan $\mathrm{KH}$ Nurdin Abdulqohhar, Direktur KPA AdDa'wah Cibadak, putra kelima Ajengan Dadun. Sukabumi, 25 November dan 15 Maret 2012.

Wawancara dengan K. Dudun Abdul Ghoffar, Ketua Yayasan AlBasyriyyah Cicantayan, tokoh masyarakat sekaligus murid dan sahabat Ajengan Dadun, Sukabumi, 5 Mei 2013.

Wawancara dengan $\mathrm{KH}$ Muhammad, tokoh masyarakat dan ketua Yayasan Majlis Ta'lim AdDa'wah. Sukabumi, 19 April 2013.
Wawancara dengan Ustadz Adun, tokoh masyarakat dan tenaga pengajar di Majlis Ta'lim dan MI Nurul Huda. Sukabumi, 11 November 2012.

\section{Informan \\ Hilman Sulaeman, tenaga pengajar dan Humas SDIT Ad-} Da'wah.

Kang Ujang, tokoh pemuda dan kepala Madrasah Nurul Huda Desa Bungbulang Tonggoh. 